\title{
Les théories de la fécondité
}

\author{
edited by Henri Leridon \\ Paris: INED 2014 \\ ISBN 978-2-7332-2024-5 \\ Softcover $\$ 43.95,512 \mathrm{pp}$.
}

\author{
Reviewed by Roderic Beaujot \\ Department of Sociology, Western University, London (Canada)
}

This volume on fertility theories is an excellent addition to INED's Série des Textes fondamentaux, which aims to highlight fundamental contributions to theoretical and conceptual development in the various areas of demography. As in the other volumes in this collection, there is a substantial integrative introduction, followed by 23 chapters taken from previously published journal articles or book chapters. The individual chapters are divided into three sections: (1) precursors (Malthus, Dumont, Landry, and Ryder), (2) structured analytic frameworks (Davis-Blake framework, Henry on natural fertility, Coale on the conditions for fertility decline, and Bongaarts on intermediate factors), and (3) thematic theoretical developments (with sub-sections entitled: historical, anthropological, institutional/political, micro-economic, sociocultural and values, birth control and family planning, gender, and other). Five of the chapters were previously published in French, and the other 18 are translated from English. Two of the 23 chapters were originally published in 1817 and 1890, another in 1909, then nine are from 1956-80, and eleven were published in the period 1981-96. While it must have been difficult to make a selection of 23 texts, this reviewer finds that excellent choices were made. However, if the collection had been put together in 2015, I would have added Goldscheider, Bernhardt, and Lappegard's "The gender revolution: Understanding changing family and demographic behavior" (2015). Besides covering the field and having survived the test of time, the chapters themselves are mostly succinct (an average of 20 pages, including references).

As editor, Henri Leridon is particularly conscientious to select theoretical statements that are useful in the context of empirical analyses. For instance, he makes only passing reference to what the French have called "Maltusianisme de pauvreté" (in a context of acceptance of birth control, reductions in living standards can bring fertility decline), because this has only been used in Latin America. He also gives little credit to aggregate-level studies that may explain a large proportion of the variance across areas, but with widely different factors entered into regression equations from study to study. Leridon (p. 13) asks how it can be that two studies each explain 90 per cent of the variation, but each with different factors. That is, while the focus is on concepts and theory, the editor pays considerable attention to developments in data collection, measurement and methods: from period to cohort and parity, from vital statistics to surveys on Knowledge Aptitude and Practice (KAP), later the World Fertility Surveys, and the Demographic and Health Surveys. However, the Gender and Generation Surveys are not mentioned.

Leridon's own introduction is also succinct (30 pages), plus 150 references, of which 20 were published since the latest article (1996). He also demonstrates a healthy acceptance of theoretical diversity in the discipline, and for lack of theoretical closure. For instance, he ends with two puzzles that he feels have not been answered: the baby boom and variations in low fertility. Elsewhere, this reviewer has suggested theoretical explanations of these two puzzles. With the benefit of hindsight, might the baby boom not be understood as a period between two transitions, where the opportunity structures of young adults were favourable to young ages at marriage, 
and gender structures involved the breadwinner model, in the context of limited access to sexual intimacy outside of marriage and inefficient contraception (Kerr and Beaujot 2016: 229). In understanding low fertility "lite" in Canada, I have proposed that we should consider the "U.S. model" in Alberta and the "Nordic model" in Quebec, with variations of these two models across the country (Beaujot and Wang 2010; Beaujot et al. 2013). That is, in some contexts, the opportunity structures of young adults permit labour force withdrawals for childbearing, in spite of limited parental leave benefits. In Quebec, and to a lesser extent elsewhere, the Nordic model may be operating (Roy and Bernier 2006), with family support in terms of parental leave, child care, and direct benefits to parents (Child Tax Benefits, Universal Child Care Benefit). More generally, with the help of studies based on the Gender and Generation Surveys, might we not say that the variation in low fertility is a function of: gender structures, opportunity structures of young adults, and extent of state support for family benefits that encourage a two-income model.

While I see Leridon's lack of theoretical closure as a healthy attitude, my own orientation is to view the demographic transition as a viable unifying framework, especially if it integrates demographic, structural, and cultural factors (Kerr and Beaujot 2016: 76-79). The demographics of the demographic transition include improved child survival and contraceptive efficiency. The structural elements include the extent to which families are units for economic production and units for the security of dependents, in contrast to other economic entities and the state (e.g., family policy). These structural questions include family nucleation à la Caldwell, opportunity structures of young adults, along with gender structures associated with women's agency, and the gender division of paid and unpaid work. MacDonald (2000) develops this concept, arguing that fertility will be particularly low if women have equity in access to the public sphere (especially for education and employment), but family structures force women to be responsible for unpaid work and the care of dependents. The cultural elements in the demographic transition include "moral restraint" à la Malthus, the acceptance of individual agency in the control of childbearing, individualism à la Lesthaeghe, and values on the side of diversity in accepting alternate family forms (including childlessness). These ideas are also rendered by Coale's necessary conditions for fertility decline, that Lesthaeghe and Vanderhoeft (2001) have rendered as "ready" given structural conditions, "willing" given the cultural context, and "able" given contraceptive efficiency and the associated steep learning curve.

This text should be required reading for students of demography. Henri Leridon's introduction is food for thought to all persons interested in understanding fertility. Since most of the articles are already available in English, let us hope that the introductory chapter will soon be translated.

\section{References}

Beaujot, R., C. Du, and Z. Ravanera. 2013. Family policies in Quebec and the rest of Canada: Implications for fertility, child care, women's paid work and child development indicators. Canadian Public Policy 39(2):221-39.

Beaujot, R., and J. Wang. 2010. Low fertility in Canada: The Nordic Model in Quebec and the U.S. Model in Alberta. Canadian Studies in Population 37(3-4):411-43.

Goldscheider, F., E. Bernhardt, and T. Lappegard. 2015. The gender revolution: Understanding changing family and demographic behavior. Population and Development Review 41(2):207-39.

Kerr, D., and R. Beaujot. 2016. Population Change in Canada. 3rd edn. Don Mills, ON: Oxford University Press.

Lesthaeghe, R., and C. Vanderhoeft. 2001. Ready, willing and able: A conceptualization of transitions to new behavioral forms, in Diffusion Processes and Fertility Decline: Selected Perspectives, edited by John B. Casterline. Washington: The National Academies Press, p. 240-64.

McDonald, P. 2000. Gender equity in theories of fertility. Population and Development Review 26:427-39.

Roy, L., and J. Bernier. 2006. La politique familiale, les tendances sociales et la fécondité au Québec : Une expérimentation du modèle nordique? Québec : Ministère de la Famille, des Aînés et de la Condition féminine. 